\title{
Penerapan Media Flash Card untuk Meningkatkan Hasil Belajar Tema "Kegiatanku"
}

\section{*Sri Wahyuni ${ }^{1}$}

${ }^{1}$ SDN Candiwatu Pacet, Mojokerto, Indonesia

\author{
A R T I C L E I N F 0 \\ Article history: \\ 25 December 2019 \\ Received in revised \\ form \\ 01 January 2020 \\ Accepted 25 January \\ 2020 \\ Available online 28 \\ February 2020 \\ Kata Kunci: \\ Hasil belajar, media \\ gambar, tema \\ Keywords: \\ Results of learning \\ pictures media \\ theme \\ science.
}

\begin{abstract}
A B S T R A K
Saat ini siswa kelas I terkadang merasa kesulitan dalam memahami materi pembelajaran melalui pembelajaran tematik.Menurut peneliti hal ini disebabkan karena siswa belum dihadapkan langsung dengan hal nyata atau kontekstual. Terlebih lagi melihat karaktertisristik anak usia kelas 1 SD adalah operasional konkrit, yaitu harus dihadapkan dengan sesuatu yang nyata. Tujuan penelitian tindakan kelas ini untuk mendeskripsikan dampak penerapan media gambar terhadap peningkatan hasil belajar siswa kelas I SD Negeri Candiwatu Kecamatan Pacet kabupaten Mojokerto pelajaran 2019/2020. Hasil penelitian menunjukkan bahwa, penerapanmedia gambar dapat meningkatkan hasil belajar siswa tematik "Kegiatanku" siswa kelas 1Sekolah Dasar Negeri Candiwatu Kecamatan Pacet Kabupaten Mojokerto semester 1 tahun pelajaran2019/2020. Dari hasil tes formatif perbaikan pembelajaran siklus I mencapai nilai rata-rata 68,33, dengan siswa yang tuntas 19siswa. Sedangkan pada siklus II rata-rata klasikal meningkat menjadi 81,67 dengan siswa yang tuntas 24 anak.tingkat pemahaman siswa tentang materi tema tersebut mengalami permasalahan, hal ini dapat
\end{abstract} ditunjukkan bahwa dari 26 siswa yang memperoleh nilai 60 ke atas hanya 19 siswa, berarti hanya $32 \%$ siswa yang tuntas, dan baru mencapai ratarata 5,5. Sedangkan hasil belajar siswa pada tema 2 "Kegemaranku" baru mencapai rata-rata kelas sebesar 5,7 dengan jumlah siswa yang mendapat nilai 60 keatas hanya 19 siswa, berarti hanya $39 \%$ siswa yang tuntas. Hal ini menunjukkan telah terjadi peningkatan hasil belajar siswa Tema Kegiatanku melalui media gambar pada siswa kelas $1 \mathrm{SD}$ Negeri Candiwatu Kecamatan Pacet Kabupaten Mojokerto Tahun Pelajaran 2019/2020.

\begin{abstract}
A B S T R A C T
At present, grade 1 students in elementary school sometimes found difficulties to understand learning material through thematic learning because students have not been confronted directly with real or contextual things The purpose of this action research was to describe the impact of application pictures media to the improvement of students' learning outcomes on the first grade students of Candiwatu elementary school, Pacet District, Mojokerto Regency, in the academic year 2019/2020. The results showed that the application of pictures media could improve the learning outcomes on the theme "Kegiatanku". From the results of the formative test, the improvement of learning on cycle I got an average score of 68.33 and 19 students passed in this test. Whereas in the second cycle, the average score improved to 81.67 and 24 students passed in this test. The level of students' understanding of the subject matter had problems. This could be showed that from the 26 students, there were only 19 students got score 60 . It meant that only $32 \%$ of students had completed the test, and only reached an average score of 5.5. While students' learning outcomes on theme 2 "My Enthusiasm" only reached an average score of 5.7. There were only 19 students got score above 60, it meant that there was only $39 \%$ of students had completed the test. It showed that there was an improvement of students' learning outcomes through the pictures media on the theme of "Kegiatanku" on first grade students of Candiwatu elementary school, Pacet District, Mojokerto Regency in the academic year 2019/2020.
\end{abstract}

\section{Pendahuluan}

Tujuan Pembelajaran pada hakekatnya adalah sebuah proses interaksi timbal balik antara guru dan siswa dalam sebuah kegiatan pembelajaran (Dimyati dan Mudjiono, 2006). Guru sebagai salah satu komponen utama serta sebagai pengatur jalannya proses pembelajaran tersebut dilaksanakan. Oleh karena itu guru hendaknya dapat membuat proses pembelajaran dapat lebih efektif, menarik dan

Copyright (C) Universitas Pendidikan Ganesha. All rights reserved 
bermakna bagi siswa sehingga tujuan pembelajaran dapat tercapai secara maksimal. Terlebih lagi pembelajaran secara tematik yang menjadi ciri khas Kurikulum SD 2013 (Cahyaningrum, 2014). Berhasilnya tujuan pembelajaran ditentukan oleh banyak faktor, salah satu diantaranya yaitu pemilihan metode pebelajaran dan penggunaan media pembelajaran yang sesuai dengan materi dan karakteristik siswa (Hayati, 2005). Dari berbagai pendekatan pembelajaran yang dapat diterapkan, seorang guru seharusnya mampu membangun sebuah interaksi pembelajaran yang bermakna bagi siswa. Pembelajaran yang bermakna disini merupakan sebuah kegiatan pembelajaran yang mampu menarik perhatian siswa, menumbuhkan minat serta motivasi siswa sehingga mereka dapat melakukan kegiatan pembelajaran dengan enjoy atau menyenangkan untuk ketercapaian hasil pembelajaran yang maksimal. Hasil pengamatan pada proses pembelajaran di SD Negeri Candiwatu menunjukkan bahwa pembelajaran tidak selalu berjalan mulus dan tercapainya tujuan pembelajaran belum secara maksimal. Tidak tercapainya tujuan pembelajaran secaramaksimalinidisebabkankarenapada kegiatan belajar mengajar (KBM) masih menggunakan metode konvensional dan pembelajaranya masih berpusat pada guru (teacher center). Terlebih lagi sejak diterapkannya Kurikulum 2013 di SDN Candiwatu. Selain itu, pada proses pembelajarannya guru masih kurang memperhatikan karakteristik siswa yang masing-masing berbeda satu sama lain (heterogen). Oleh sebab itu penggunaan metode pembelajaran dan media pembelajaran sangatlah penting, sesuai dengan materi dan karakteristik siswa pada saat proses pembelajaran agar tercapainya tujuan pembelajaran yang diharapkan.

Pengertian media flash card dijelaskanoleh Susilana, Riana dan Riyana, (2009), yaitu: "Flash card adalah media pembelajaran dalam bentuk kartu bergambar yang berukuran $25 \times 30 \mathrm{~cm}$. Gambargambarnya dibuat menggunakan tangan atau foto, atau memanfaatkan gambar atau foto yang sudah ada yang ditempelkan pada lembaran-lembaran flash card" (Dananjaya, 2010; Maghfiroh, 2013). Dari uraian tersebut dapat dikatakan bahwa flash card merupakan media yang berbentuk kartu bergambar yang dibuat dengan menggunakan foto atau gambar, pada bagian belakang terdapat keterangan dari gambar yang ada pada flash card tersebut. Dari kutipan tersebut dijelaskan ukuran flash card $25 \times 30 \mathrm{~cm}$, akan tetapi Arsyad, (2007) memiliki pendapat yang berbeda seperti diungkapkan sebagai berikut:"Flash cardbiasanya berukuran $8 \times 12 \mathrm{~cm}$ atau dapat disesuaikan dengan besar kecilnya kelas yang dihadapi, kartu-kartu tersebut berisi gambar-gambar (binatang, benda, buah-buahan dan sebagainya) dapat digunakan untuk melatih mengeja dan memperkaya kosakata".Berdasarkan pendapat Arsyad tersebut, dapat dijelaskan bahwa ukuran flash card adalah $8 \times 12 \mathrm{~cm}$ atau biasa disesuaikan dengan keadaan siswa yang dihadapi, apabila jumlah siswa banyak maka flash card dibuat dengan ukuran yang lebih besar dan jika jumlah siswa sedikit maka flash card dibuat dengan ukuran kecil.Selain itu menurut Izzan(dalam Hotimah, 2010)mengemukakan bahwa: "Flash card merupakan alat peraga dari koran berukuran 18x 16 inci yang dibubuhi gambar-gambar menarik, kata, ungkapan, atau kalimat. Menurut Suryana (dalam Hotimah, 2010) mengemukakan bahwa:"Flash card merupakan salah satu bentuk permainan edukatif berupa kartu-kartu yang memuat gambar dan kata yang sengaja dirancang oleh doman untuk meningkatkan berbagai aspek diantaranya: mengembangkan daya ingat, melatih kemandirian dan meningkatkan jumlah kosakata."Flash card adalahkumpulan kartu yang berisi kata ataukombinasi kata dan gambar. Bergunauntuk media belajar membaca dan jugamengenal bentuk, benda, hewan, matematika, dan jenis aktivitas lainnya (Hidayanti, 2017; Damayanti, 2016). Dari beberapa pengertian diatas dapat disimpulkan bahwa flash cardadalah salah satu bentuk media edukatif berupa kartu yang memuat gambar dan kata yang ukurannya bisa disesuaikan dengan siswa yang dihadapi dan untuk mendapatkannya bisa membuat sendiri atau menggunakan yang sudah jadi.

Media ini merupakan media pembelajaran yang dapat membantu dalam meningkatkan berbagai aspek seperti: mengembangkan daya ingat, melatih kemandirian dan meningkatkan jumlah kosa kata (Hotimah, 2010; Inggrida, 2015; Safitri, 2018). Media flashcard merupakan media yang membantu dalam mengingat dan mengkaji ulang bahan pelajaran seperti: definisi atau istilah, simbol-simbol, ejaan bahasa asing, rumus-rumus, dan lain-lain (Maryanto, 2019; Komalasari, 2016; Iswari, 2017). Media Kartu memiliki beberapa kelebihan, diantaranya yaitu bahan cukup murah, mudah diperoleh di lingkungan sekitar, mudah disusun dan digunakan, mudah dipindahkan karena bahan ringan serta mampu memvisualkan urutan basa-basa nitrogen dalam sebuah nukleotida (Mulyani, 2017; Setiawati, 2015; Zubaidillah, 2019). Selain itu media ini dapat disusun berjajar, dihilangkan atau digandakan sehingga akanmerangsang peserta didik untuk aktif belajar dan dapat membantu peserta didik adanya pergeseran kerangka DNA jika terjadi suatu mutasi.Menurut Munthe, (2018) flashcard merupakan kartu dengan dua sisi. Sisi satu bertuliskan kata, sementara pada sisi lainnya ada gambar yang sesuai dengan kata.Fungsi utama dari gambar adalah untuk melatih daya ingat siswa terhadap kata yang sedang dipelajari (Umainingsih, 2017; Febriyanto, 2019; Umroh, 2019). Menurut Hotimah, (2010) juga menyatakan bahwa keunggulan dari media flashcard adalah membantu kemampuan otak kanan untuk mengingat gambar dan kata - kata sebagai komponennya. Melalui pendapat beberapa ahli di atas maka kelebihan media flashcard 
adalah mudah dibawa, praktis, gampang diingat, dan menyenangkan. Menurut Angreany, (2017)Flash card merupakan salah satu media pembelajaran yang berbentuk grafis berupa kartu kecil bergambar, biasanya terbuat dengan menggunakan foto, simbol, atau gambar yang ditempelkan pada sisi depan dan pada sisi belakang terdapat keterangan berupa kata atau kalimat dari gambar Flashcard tersebut. Media pembelajaran Flashcard mengingatkan atau mengarahkan siswa kepada sesuatu yang berhubungan dengan gambar.

Keberhasilan proses belajar mengajar sampai saat ini hanya diukur dari tinggirendahnya nilai yang diperoleh siswa dalam melaksanakan tes (Effendy, 2016). Padahal pada kurikulum 2013 pada Kompetensi Inti 1 lebih mengutamakan aspek religius, KI 2 aspek pengetahuan, KI 3 aspek sosial, dan KI 4 aspek keterampilan. Berdasarkan hasil ulangan harian siswa pada Tema 1 "Kegiatanku" siswa kelas 1A SD Negeri Candiwatu Tahun pelajaran 2019/2020 Kecamatan Pacet Kabupaten Mojokerto dapat dianalisis bahwa tingkat pemahaman siswa tentang materi tema tersebut mengalami permasalahan, hal ini dapat ditunjukkan bahwa dari 26 siswa yang memperoleh nilai 60 ke atas hanya 19 siswa, berarti hanya 32\% siswa yang tuntas, dan baru mencapai ratarata 5,5. Sedangkan hasil belajar siswa pada tema 2 "Kegemaranku" baru mencapai rata-rata kelas sebesar 5,7 dengan jumlah siswa yang mendapat nilai 60 keatas hanya 19 siswa, berarti hanya 39\% siswa yang tuntas. Berdasarkan hasil belajar siswa pada tematema sebelumnya, peneliti menganalisis bahwa ada kesulitan yang cukup berarti bagi siswa kelas I dalam memahami materi pembelajaran melalui pembelajaran tematik, maka peneliti men- gupayakan untuk meningkatkan hasil belajar siswa kelas 1 SDN Candiwatu. Menurut peneliti hal ini disebabkan karena siswa belum dihadapkan langsung dengan hal nyata atau kontekstual. Terlebih lagi melihat karaktertisristik anak usia kelas 1 SD adalah operasional konkrit, yaitu harus dihadapkan dengan sesuatu yang nyata. Dalam penyampaiannya juga masih didominasi oleh guru yang hanya mengandalkan metode ceramah yang kurang bervariasi atau hanya satu metode saja. Oleh sebab itu peneliti berusaha untuk melakukan perbaikan pembelajaran pada tema selanjutnya yang dilakukan dalam perbaikan pembelajaran. Berdasarkan latar belakang masalah tersebut, maka peneliti menyusun sebuah penelitian tindakan dengan judul "Penerapan Media Pembelajaran Flash Card untuk meningkatkan hasil belajarTema "Kegiatanku" siswa kelas IA SDN Candiwatu Pacet Kab. Mojokerto tahun ajaran 2019-2020"

\section{Metode}

Kegiatan yang dilakukan oleh peneliti pada tahap perencanaan adalah: 1) Peneliti melakukan analisis kurikulum untuk menentukan standar kompetensi dan kompetensi dasar yang disampaikan kepada siswa dengan menggunakan pembelajaran dengan media flash card. 2) Membuat RPP siklus I dengan model pembelajaran dengan media pebelajaran flash card.Membuat lembar observasi siklus I untuk melihat bagaimana kondisi belajar mengajar dikelas ketika latihan dan kerja kelompok dilaksanakan. 3) Membuat Lembar Kerja Siswa siklus I. 4) Membentuk kelompok yang bersifat heterogen baik dari segi kemampuan akademis, jenis pembelajaran dengan menggunakan media pembelajaran flash cardpada siklus I. 5) Menyusun alat evaluasi pembelajaran berdasarkan perkembangan untuk dilaksanakan pada siklus II serta menyiapkan instrumen pendukung pembelajaran lainnya.

Selama pembelajaran langsung dilakukan observasi untuk mengetahui penggunaan media pembelajaran flash card dalam meningkatkan hasil belajar tema kegiatankupada proses pembelajaran teamtik. Langkah selanjutnya bagi peneliti adalah pelaksanaan. Pada tahap ini perencanaan yang sudah dibuat peneliti akan dilaksanakan dalam kegiatan pembelajaran. Tahap pengamatan atau observasi dilakukan bersamaan dengan pelaksanaan tindakan. Pada tahap ini peneliti di bantu oleh guru atau teman sejawat untuk mencatat semua hal yang diperlukan dalam penelitian berupa pengumpulan datadata.Ketika dilaksanakan kegiatan tema kebanyakan siswa yang tidak tahu dan tidak paham, sehingga tidak bisa menjawab pertanyaan yang berkenaan dengan soal kegiatanku Karena ketidakpahaman dan ketidakmapuan daam menjawab soal-soal tema, suasana kelas tampak gaduh dan sulit dikendalikan.

\section{Hasil dan Pembahasan}

Data hasil pretes kelompok siswa sebelum mendapat Pembelajaran dengan menggunakan media pembelajaran Flash card, dianalisis dengan untuk mengetahui tingkat pengetahuan dan pemahaman tentang materi belajar yang berhubungan dengan tema "kegiatanku".Berdasarkan hasil observasi dan tindakan terlihat bahwa nilai pretes kelompok siswa sebelum mendapat perlakuan pembelajaran dengan media pembelajaran Flash card adalah 69,00. 


\section{Siklus I}

Perencanaan di mulai dengan membentuk kelompok diskusi.Siswa yang berjumlah 26 siswa dibagi menjadi 4 kelompok sehingga masing-masing kelompok berjumlah 5 siswa.Materi pelajaran yang diajarkan pada siklus I ini adalah pokok bahasan Kegiatanku Proses pembelajaran ini menggunakan media pembelajaran Flash cardyang diterapkan oleh guru secara langsung dalam pembelajaran di kelas.Kegiatan yang dilakukan oleh peneliti pada tahap perencanaan adalah: 1) Peneliti melakukan analisis kurikulum untuk menentukan standar kompetensi dan kompetensi dasar yang disampaikan kepada siswa dengan menggunakan pembelajaran Flash Card. Membuat RPP siklus I dengan model pembelajaran dengan media pembelajaran Flash card. 2) Membuat lembar observasi siklus I untuk melihat bagaimana kondisi belajar mengajar dikelas ketika latihan dan kerja kelompok dilaksanakan. 3) Membuat Lembar

Kerja Siswa siklus I. 4) Membentuk kelompok (terdiri dari 5 siswa) yang bersifat heterogen baik dari segi kemampuan akademis, jenis pembelajaran dengan media pembelajaran Flash card pada siklus I. dan 5) Menyusun alat evaluasi pembelajaran berdasarkan perkembangan pada siklus II serta menyiapkan instrumen pendukung pembelajaran lainnya.

Pelaksanaan kegiatan belajar mengajar pembelajaran dengan media pembelajaran Flash carduntuk siklus I dengan jumlah siswa 20 siswa. Dalam hal ini Peneliti bertindak sebagai guru.Pengamatan (observasi) dilaksanakan bersamaan dengan pelaksanaan pembelajaran. Pelaksanaan tindakan siklus I dapat diuraikan sebagai berikut: 1) Guru mengawali pembelajaran dengan mengucapkan salam dan menanyakan jumlah siswa yang hadir. 2) Guru melaksanakan apersepsi. 3) Guru membagi siswa dalam kelompok diskusi, kemudian memberi tugas yang berkaitan dengan penggunaan media pembelajaran Flash card. 4) Guru memberi tugas kepada siswa untuk mempresentasikan di depan kelas hal-hal yang berkaitan dengan "Kegiatanku" atas dengan menggunakan pembelajaran media pembelajaran Flash card, waktu untuk presentasi adalah 5 menit untuk masing-masing individu. 5) Guru menindaklanjuti pembelajaran itu dengan menerangkan materi pelajaran tentang hal-hal yang berkaitan dengan "kegiatanku"menggunakan pembelajaran pendekatan media pembelajaran Flash card, waktu yang digunakan selama 10 menit. 6) Guru bersama-sama siswa mendemonstrasikan penggunaan pembelajaran flash Card tema"kegiatanku". selama 10 menit. 7) Guru bersama-sama siswa melakukan kegiatan pembelajaran dengan tema "kegiatanku" 8) Guru memberikan tugas secara individu selama 15 menit dan 9) Guru menutup pelajaran dengan mengucapkan salam.

Dalam siklus pertama ini, berdasarkan catatan peneliti, siswa masih kurang dapat bekerja sama, kerja kelompok masih kurang dapat berjalan sebagaimana yang diharapkan, presentasi belum banyak mendapat perhatian/tanggapan dari pendengar (siswa dari kelompok lain).

Selama pembelajaran berlangsung dilakukan observasi untuk mengetahui pengaruh kegiatan pembelajaran dalam meningkatkan hasil belajar siswa tema "kegiatanku".Pada pembelajaran ini siswa yang masuk sebanyak 26 siswa. Guru mengamati, ternyata pada setiap kelompok masih didapati siswa yang kurang memperhatikan pelajaran yang berkaitan dengan tema "kegiatanku" dan masih berbicara dengan teman didekatnya tentang hal-hal yang tidak berkaitan dengan materi pembelajaran. Melalui serangkaian pertanyaan yang disampaikan kepada siswa, sebagian diantaranya belum memahami dan bahkan tidak tau apa yang di diskusikan dalam kelompoknya. Adapun hasil belajar siswa setelah kegiatan yang diberikan dalam Siklus I, dapat dilihat pada gambar 1:

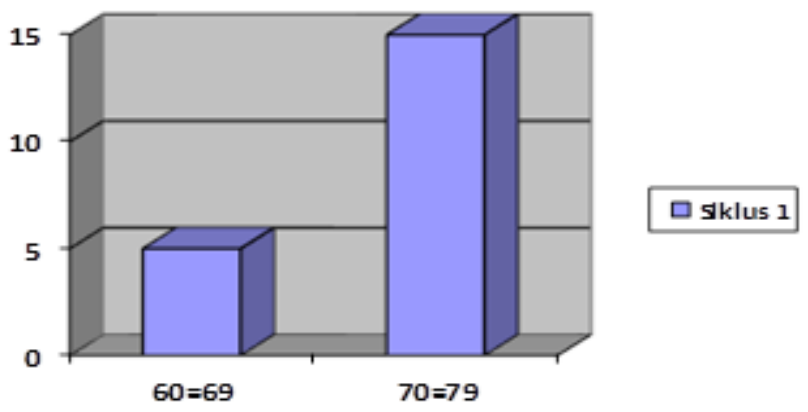

Gambar 01

Hasil Belajar Siswa dalam Siklus 1

Dari gambar di atas dapat diketahui bahwa dengan menerapkan pembelajaran dengan media pembelajaran Flash cardtampak bahwa nilai rata-rata siswa adalah 70,28 dengan nilai terendah 60 dan nilai tertinggi 79. Nilai ketuntasan belajar adalah 7,0 jumlah siswa yang mendapat nilai $\geq 7,0$ sebanyak 
17siswa,yang berarti $60 \%$ dari sejumlah 20 siswa memiliki nilai di atas taraf penguasaan konsep yang diberikan, lebih kecil dari persentase ketuntasan yang dikehendaki yaitu sebesar $95 \%$. Hal ini disebabkan karena siswa masih baru dan asing terhadap metode baru yang diterapkan dalam proses belajar mengajar. Sehingga dapat dikatakan siswa belum banyak memahami tentang konsep pokok bahasan yang dibahas.

Dalam pelaksanaan kegiatan belajar mengajar pada siklus I yang masih terdapat kekurangankekurangan, Maka perlu adanya revisi untuk dilakukan pada siklus II antara lain : 1) Guru dalam memotifasi siswa hendaknya dapat membuat siswa lebih termotivasi selama proses belajar mengajar berlangsung. 2) Guru harus lebih dekat dengan siswa sehingga tidak ada perasaan takut dalam diri siswa, sehingga siswa lebih berkosentrasi dalam pembelajaran. 3) Guru harus lebih bersabar dalam membimbing siswa berdiskusi untuk menemukan hal-hal baru yang berkaitan dengan materi pembelajaran. 4) Guru secara intensif memberikan pengertian kepada siswa kondisi dalam berkelompok, kerjasama kelompok, dan keikutsertaan siswa dalam kelompok. 5) Guru mengubah jumlah siswa (dari 5 siswa menjadi 4 siswa) dalam satu kelompok. 6) Guru membantu kelompok yang belum memahami langkah-langkah pembelajaran dengan media Flash card. 7) Guru memberikan dorongan dan motivasi kepada siswa untuk lebih aktif mencari sumber belajar, diharapkan agar siswa memperoleh hasil yang diharapkan.

\section{Siklus II}

Perencanaan di mulai dengan membentuk kelompok diskusi.Siswa yang berjumlah 26 siswa dibagi menjadi 5 kelompok sehingga masing-masing kelompok berjumlah 4 siswa. Materi pelajaran yang diajarkan pada siklus II ini tetap pada pokok bahasan "kegiatanku".Proses pembelajaran pokok bahasan ini menggunakan media pembelajaran Flash card yang diterapkan oleh guru secara langsung dalam pembelajaran di kelas. Kegiatan yang dilakukan oleh peneliti pada tahap perencanaan pada siklus II adalah: 1) Peneliti melakukan analisis kurikulum untuk menentukan Standar Kompetensi dan Kompetensi Dasar yang disampaikan kepada siswa dengan menggunakan media pembelajaran Flash card. 2) Membuat RPP dengan model pembelajaran media Flash card siklus II. 3) Membuat lembar observasi siklus II untuk melihat bagaimana kondisi belajar mengajar di kelas ketika latihan dan kerja kelompok dilaksanakan. 4) Membuat Lembar Kerja Siswa siklus II. 5) Membentuk kelompok (terdiri dari 4 siswi) yang bersifat heterogen baik dari segi kemampuan akademis,dengan menggunakan pembelajaran pendekatan permainan pada siklus II. 6) Menyusun alat evaluasi pembelajaran berdasarkan perkembangan pada siklus II serta menyiapkan instrumen pendukung pembelajaran lainnya

Pelaksanaan kegiatan belajar mengajar dengan model pembelajaran menggunakan media Flash card untuk siklus II dilaksanakan di kelas IA SDN Candiwatu Pacet dengan jumlah siswa 26.Tema "kegiatanku. Dalam hal ini Peneliti bertindak sebagai guru.Pengamatan (observasi) dilaksanakan bersamaan dengan pelaksanaan pembelajaran.Pelaksanaan tindakan disesuaikan dengan RPP (Rencana Pelaksanaan Pembelajaran) dan lembar kerja yang telah dibuat dan mengacu pada revisi siklus I, sehingga kekurangan-kekurangan pada siklus I tidak terulang pada siklus II. Adapun proses belajar mengajar mengacu pada rencana pembelajaran yang telah dipersiapkan dengan menggunakan media pembelajaran Flash card, dengan tahapan, presentasi kelas, kerja kelompok, tes individu,dan penghargaan kelompok.

Pelaksanaan tindakan siklus II dapat diuraikan sebagai berikut: 1) Guru mengawali pembelajaran dengan mengucapkan salam dan menanyakan jumlah siswa yang hadir. 2) Guru melaksanakan apersepsi. 3) Guru membagi siswa dalam kelompok diskusi, kemudian memberi tugas yang berkaitan dengan penggunaan media pembelajaran Flash card. 4) Guru memberi tugas kepada siswa untuk mempresentasikan di depan kelas hal-hal yang berkaitan 'Kegiatanku' dengan menggunaan media pembelajaran flash card waktu untuk presentasi adalah 3 menit untuk masing-masing kelompok. 5) Guru menindaklanjuti pembelajaran itu dengan menerangkan materi pelajaran tentang hal-hal yang berkaitan dengan "kegiatanku"atas menggunakan media pembelajaran Flash Cardwaktu yang digunakan selama 10 menit. 6) Guru bersama-sama siswa mendemonstrasikan penggunaanmedia flash card pada tema “kegiatanku"selama 10 menit. 7) Guru bersama-sama siswa melakukan pembelajaran dengan tema "kegiatanku" 8) Guru memberikan tugas secara individu selama 15 menit. Dan 9) Guru menutup pelajaran dengan mengucapkan salam.

Selama pembelajaran berlangsung dilakukan observasi untuk mengetahui penerapan Permainandalam meningkatkan hasil belajar siswa dalam proses pembelajaran tema "kegiatanku". Pada pembelajaran ini siswa yang masuk sebanyak 26. siswa.Bila dilihat dari angka aktivitas guru dan siswa selama kegiatan belajar mengajar, maka secara keseluruhan aktivitas guru dan siswa menunjukkan pembelajaran yang berorientasi pendekatan keterampilan proses dalam setting pembelajaran denganmedia Flash card yang berpusat pada siswa, dimana siswa terlibat aktif dalam pembelajaran. 
Pada akhir proses belajar mengajar siklus II siswa diberi tes dengan tujuan untuk mengetahui tingkat keberhasilan siswa dalam proses belajar mengajar yang sudah dilakukan di siklus I, kemudian dikomparasikan dengan hasil pada siklus II .Dalam pembelajaran siklus II, konsep-konsep yang teridentifikasi dikembangkan lebih lanjut.Dalam Siklus II ini, berdasarkan catatan peneliti, kerjasama siswa sudah berjalan dengan baik, sehingga masing-masing siswa dapat memecahkan masalah secara individual. Adapun data hasil tes pada siklus II adalah sebagai berikut ditunjukkan pada gambar 2:

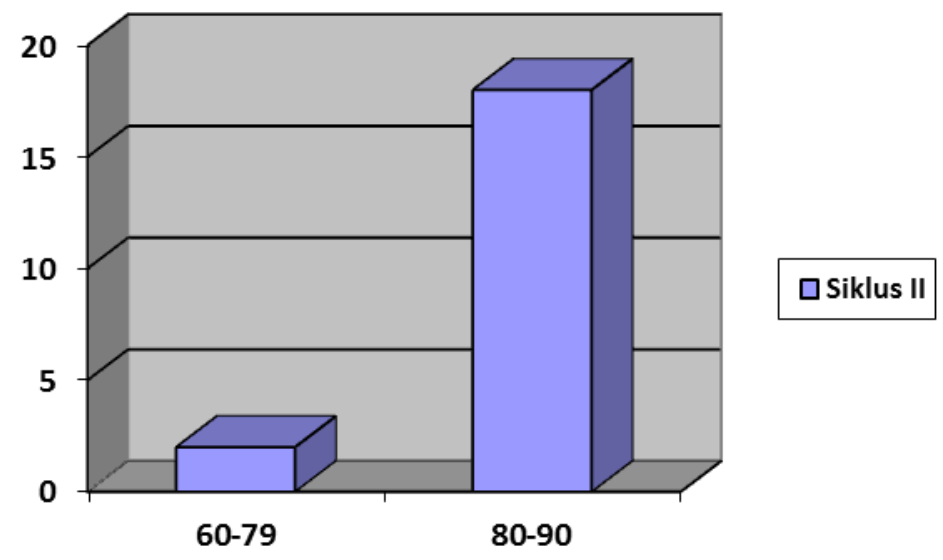

Gambar 2

Nilai Tes Formatif Siswa dalam Siklus 2

Dari gambar di atas tampak bahwa hasil nilai evaluasi rata-rata siswa secara individual adalah 80,4 dengan nilai terendah 60 dan nilai tertinggi 90. Data diatas menunjukkan bahwa pada siklus II ini, nilai siswa secara individual mengalami peningkatan, yaitu siswa yang tuntas sebanyak 19 siswa dan yang belum tuntas sebanyak 1 siswa, yang berarti 90\% dari sejumlah 20 siswa memiliki nilai di atas taraf penguasaan konsep yang diberikan. Dari siklus 2 ini dapat dikatakan bahwa proses pembelajaran dengan media pembelajaran Flash card pembelajaran kartu bergambar dapat meningkatkan hasil belajar siswa.

Dalam pelaksanaan kegiatan belajar mengajar pada siklus II ini masih terdapat kekurangankekurangan. Pada tahap ini akan merefleksikan kembali apa yang telah dilaksanakan selama penelitian tindakan kelas dilakukan. Dari data yang diperoleh dapat diuraikan sebagai berikut: 1) Selama proses belajar mengajar guru telah melaksanakan pembelajaran dengan cukup baik dengan metode pembelajaran flash cardpembelajaran kartu bergambar, meskipun ada beberapa bagian yang masih belum sempurna, tetapi presentasi pelaksanaan untuk masing-masing kegiatan sudah cukup baik. 2) Berdasarkan data hasil lembar observasi kegiatan kelompok siswa, diadakan perubahan jumlah kelompok pada siklus I sebanyak 5 siswa, dan pada siklus II sebanyak 2 siswa. 3) Kekurangan pada siklus I diperbaiki, sehingga pembelajaran menjadi lebih baik pada siklus II. Dan 4) Hasil evaluasi siswa mengalami peningkatan dari siklus I ke siklus II,dan telah mencapai ketuntasan belajar pada siklus II ini sesuai yang diharapkan yakni peningkatan hasil belajar siswa.

Sebelum perlakuan diberikan pada masing-masing kelompok, nilai rerata pretes siswa sebelum diberi perlakuan pembelajaran dengan media Flash card adalah 69,00. Setelah siswa diberi perlakuan pembelajaran dengan media pembelajaran Flash card pada siklus I mengalami peningkatan menjadi 70.28, namun hasil ini belum memenuhi target hasil belajar siswa mata pelajaran tematik yaitu 95\%.Bila dihitung berdasarkan nilai rerata pretes, kelompok siswa yang diberi perlakuan pembelajaran dengan Flash Card setelah dilaksanaknnya siklus ke II mengalami peningkatan rerata hasil belajar sebesar 80,400$69,00=11,600$.

Berdasarkan hasil pada sisklus penelitian tersebut di atas, dapat ditunjukkan bahwa ada perbedaan hasil belajar tema "Kegiatanku" antara siswa yang diajar menggunakan metode pembelajaran dengan dibantu media Flash Card. Hasil penelitian ini juga didukung oleh hasil penelitian Sari \& Kurniaman (2019) yang menyatakan bahwa ada perbedaan hasil belajar siswa yang yang mendapat perlakuan pembelajaran dengan medial pembelajaran Flash Card memperoleh rata-rata nilai sebesar 80,400, lebih tinggi daripada sebelum siswa diajar dengan model pembelajaran lainnya, yaitu 69,00. Penerapan media flash card memberikan peningkatatan yang lebih baik pada perolehan hasil belajar tema "kegiatanku" daripada penerapan pembelajaran dengan metode lainya. Dengan kata lain dapat di interpretasikan bahwa penerapan pembelajaran dengan Flash Card dapat meningkatkan perolehan hasil belajar siswa pada tema "Kegiatanku". 


\section{Simpulan dan Saran}

Penerapan pembelajaran dengan media flash card peningkatan yang lebih baik pada perolehan hasil belajar tema "kegiatanku"daripada penerapan pembelajaran dengan metodel senbelumnya. Dengan kata lain dapat diinterpretasikan bahwa penerapan pembelajaran dengan media Flash Carddapat meningkatkan perolehan hasil belajar siswa pada tema "kegiatanku"daripada dengan model pembelajaran konvensinal. Hal ini berdasarkan nilai rerata pretes dimana rata-rata hasil belajar siswa sebesar 69,00, sedangkan setelah siswa diberi perlakuan pembelajaran dengan media flash card setelah dilaksanakannya siklus ke II mengalami peningkatan rerata hasil belajar sebesar 80,400 artinya terjadi peningkatan rerata hasil belajar siswa sebesar 11,600.

\section{Daftar Rujukan}

Angreany, F. dan S. S. (2017). Keefektifan Media Pembelajaran Flashcard dalam Keterampilan Menulis Karangan Sederhana Bahasa Jerman Siswa Kelas XI IPA SMA Negeri 9 Makassar. Jurnal Pendidikan Bahasa Asing Dan Sastra, 1(2), 138-146.

Arsyad, A. (2007). Media Pembelajaran. Jakarta: Raja Grafindo Persada.

Cahyaningrum, U. dan I. P. (2014). Pengaruh Penggunaan Media Flash Card Terhadap Motivasi Dan Hasil Belajar Siswa Kelas II Sd N 1 Ngronggah Blora, 357-356.

Damayanti, E. dkk. (2016). Pengembangan Media Visual Flash Card pada Materi Interaksi Makhluk Hidup dengan Lingkungannya. Jurnal Sainsmat, 5(2), 175-182.

Dananjaya, U. (2010). Media Pembelajaran Aktif. Nuansa.

Dimyati dan Mudjiono. (2006). Belajar dan Pembelajaran. Jakarta: PT Rineke Cipta.

Febriyanto, B. \& A. Y. (2019). Penggunaan media Flash Card untuk Meningkatkan Hasil Belajar Siswa Sekolah Dasar. Jurnal Komunikasi Pendidikan, 3(2), 108-116.

Hayati, N. (2005). Media Pengajaran. Surabaya: Dakwah Digital Pres.

Hotimah, E. (2010). Penggunaan Media Flashcard Dalam dalam Meningkatkan Kemampuan Siswa pada Pembelajaran Kosakata Bahasa Inggris Kelas II MI AR-Rochman Semarang Garut. Jurnal Pendidikan Universitas Garut, 04(01), 10-19.

Maghfiroh, L. (2013). Penggunaan Media Flascard Untuk Meningkatkan Hasil Belajar IPS Pada pembelajaran Tematik Di Sekolah Dasar. JPGSD, 1(2), 0-216.

Maryanto, R. I. P. dan I. A. W. C. (2019). Penggunaan Media Flascard untuk Meningkatkan Pengenalan Bentuk Huruf Siswa Kelas I pada Mata Pelajaran Bahasa Indonesia di Sekolah ABC Manado. Jurnal Ilmu Pendidikan.

Mulyani, S. (2017). Penggunaan Media Kartu (Flash Card) dalam Meningkatkan Hasil Belajar Konsep Mutasi bagi Peserta Didik Kelas XII. Jurnal Profesi Keguruan, 3(2), 143-148.

Munthe, A. P. (2018). Manfaat serta KendalaMenerapkan Flashcard pada Pelajaran Membaca Permulaan. $J D P, 11(3), 210-228$.

Safitri, R. W. (2018). Pengembangan media flashcard tematik berbasis permainan tradisional untuk kelas IV sub tema lingkungan tempat tinggalku. Jurnal Pendidikan Dasar Dan Pembelajaran, 8(1).

Sari, E. R. \& O. K. (2019). Penggunaan Media Kartu Bergambar Untuk Meningkatkan Kemampuan Membaca Siswa Kelas II SDN 067 Pekanbaru. Jurnal Pendidikan Guru Sekolah Dasar, 82. 
Setiawati, Ni Luh Made, Nyoman Dantes, dan I. M. C. (2015). Pengaruh Penggunaan Media Gambar Flash Card Terhadap Minat Dan Hasil Belajar IPAPeserta Didik Kelas VI SDLBB Negeri Tabanan. E-Journal Program Pascasarjana Universitas Pendidikan Ganesha, 5(1).

Susilana, Riana dan Riyana, C. (2009). Media pembelajaran. Bandung: Wacana Prima.

Umainingsih, M. B. dkk. (2017). PENERAPAN MODEL PEMBELAJARAN MEMORI UNTUK MENINGKATKAN DAYA INGAT DAN PRESTASI BELAJAR MATEMATIKA (Studi pada siswa kelas III SD Gugus II Kecamatan Ipuh). Jurnal Ilmiah Teknologi Pendidikan, 7(2).

Umroh, I. L. (2019). Pengaruh Penggunaan Media Flash Card Terhadap Pembelajaran Kosa Kata Bahasa Arab (Study Eksperimen Terhadap Siswa Kelas 1 SD Negeri Tlogorejo Sukodadi Lamongan). Jurnal Studi Keagamaan, Pendidikan Dan Humaniora, 6(1).

Zubaidillah, M. H. \& H. (2019). Pengaruh Kartu Bergambar (Flash Card) Terhadap Penguasaan Kosakata Bahasa Arab. Jurnal Al Mi'yar, 2(1). 